\title{
Treatment for overweight and obesity in adult populations: a systematic review and meta-analysis
}

\author{
Leslea Peirson PhD, James Douketis MD, Donna Ciliska PhD, Donna Fitzpatrick-Lewis MSc, \\ Muhammad Usman Ali MD MSc, Parminder Raina PhD
}

\section{Abstract}

Background: Obesity is a major public health issue. This review updates the evidence on the effectiveness of behavioural and pharmacologic treatments for overweight and obesity in adults.

Methods: We updated the search conducted in a previous review. Randomized trials of primary care-relevant behavioural (diet, exercise and lifestyle) and pharmacologic (orlistat and metformin) with or without behavioural treatments in overweight and obese adults were included if 12-month, postbaseline data were provided for weight outcomes. Studies reporting harms were included regardless of design. Data were extracted and pooled wherever possible for 5 weight outcomes, 6 secondary health outcomes and 4 adverse events categories.

Results: We identified 68 studies: most consisted of short-term ( $\leq 12 \mathrm{mo})$ treatments using diet $(n=8)$, exercise $(n=4)$, diet and exercise $(n=10)$, lifestyle $(n=19)$, orlistat $(n=25)$ or metformin $(n=4)$. Compared with the control groups, intervention participants had a greater mean weight loss of $-3.02 \mathrm{~kg}$ (95\% confidence interval [Cl] -3.52 to -2.52$)$, a greater reduction in waist circumference of $-2.78 \mathrm{~cm}(95 \% \mathrm{Cl}-3.34$ to -2.22$)$ and a greater reduction in body mass index of $-1.11 \mathrm{~kg} / \mathrm{m}^{2}(95 \% \mathrm{Cl}-1.39$ to -0.84$)$. The relative risk for loss of $\geq 5 \%$ body weight was 1.77 ( $95 \% \mathrm{Cl} 1.58$ to 1.99 ; number needed to treat $5,95 \% \mathrm{Cl} 4$ to 7 ), and the relative risk for loss of $\geq 10 \%$ body weight was 1.91 (95\% Cl 1.69 to 2.16 ; number needed to treat $9,95 \% \mathrm{Cl} 7$ to 12 ). Incidence of type 2 diabetes was lower among prediabetic intervention participants (relative risk $0.62,95 \% \mathrm{Cl} 0.50$ to 0.77 ; number needed to treat $17,95 \% \mathrm{Cl} 13$ to 29 ). With prevalence rates for type 2 diabetes on the rise, weight loss coupled with a reduction in the incidence of type 2 diabetes could potentially have a significant benefit on population health and a possible reduction in need for drug treatments for glycemic control.

Interpretation: There is moderate quality evidence that behavioural and pharmacologic plus behavioural treatments for overweight and obesity in adults lead to clinically important reductions in weight and incidence of type 2 diabetes in prediabetic populations. Registration: PROSPERO no. CRD42012002753

verweight and obesity are defined by a body mass index (BMI) of 25-29.9 and $\geq 30 \mathrm{~kg} / \mathrm{m}^{2}$, respectively. An estimated one billion adults are overweight and at least 300 million are obese worldwide, with prevalence increasing in most countries. ${ }^{1}$ Obese adults are at increased risk for developing major diseases, such as type 2 diabetes, coronary artery disease, stroke, depression and certain cancers. $^{2-4}$ It is estimated that one in 10 premature adult deaths is directly attributable to overweight and obesity. .,6 $^{5}$

We provide an updated synthesis of the effectiveness of behavioural and pharmacologic interventions for treating overweight and obesity in adults. Whereas most systematic reviews on this topic have focused on anthropometric (e.g., weight and waist circumference $)^{7,8}$ and biochemical outcomes (e.g., cholesterol and blood pressure), ${ }^{9-11}$ we aimed to also assess the effects of nonsurgical weight-loss interventions on clinically meaningful outcomes (e.g., $5 \%$ weight loss and incidence of type 2 diabetes).

\section{Methods}

\section{Search strategy}

A recent high-quality (9/11 AMSTAR rating) ${ }^{12}$ review by the United States Preventive Services Task Force ${ }^{13}$ examined interventions for preventing obesity in overweight and obese populations. To avoid duplication, our protocol was designed to update their search. We searched MEDLINE, Cochrane Central Register of Controlled Trials, PsycINFO and Embase

Competing interests: See end of article.

This article has been peer reviewed.

Correspondence to: Leslea Peirson, peirson@mcmaster.ca

CMAJ Open 2014.DOI:10.9778/cmajo.20140012 
from September 2010 (the date of the last United States Preventive Services Task Force search) up to and including Apr. 19, 2013. The full search strategy is provided in Appendix 1 (available at www.cmajopen.ca/content/2/4/E306/suppl /DC1). Reference lists from other systematic reviews were searched for studies not captured by our search.

\section{Population, intervention, comparator, outcome and setting statement}

Details regarding the population, intervention, comparator, outcomes and setting for this review are provided in Box 1 .

\section{Inclusion and exclusion criteria}

The inclusion and exclusion criteria for this review are provided in Box 2.

\section{Study selection, quality assessment and data abstraction}

Titles and abstracts of papers were reviewed independently by 2 team members. Any citation marked for inclusion by either team member went on to full-text screening, which was also done independently by 2 researchers. Randomized controlled trials were assessed using the Cochrane Collaboration's tool for risk-of-bias assessment ${ }^{14}$ (Appendix 2, available at www.cmaj open.ca/content/2/4/E306/suppl/DC1). Overall strength of the

Box 1: Description of population, intervention, comparator, outcomes and setting

Population

- Overweight (BMI 25-29.9 kg/m²) and obese (BMI 30-39.9 kg/m²) adults aged 18 years and older

Interventions

- Behavioural (diet, exercise or lifestyle) and pharmacologic (orlistat or metformin) treatments for weight loss

Comparator

- Treatment effectiveness: no intervention, usual care, placebo or minimal intervention (e.g., newsletter or single information session on healthy living)

- Treatment harms: any type of comparison group or no comparison group

Outcomes

- Treatment effectiveness: Primary weight outcomes: weight change in $\mathrm{kg}$, loss of $\geq 5 \%$ and $\geq 10 \%$ baseline body weight, change in BMI, change in waist circumference. Secondary health outcomes: total cholesterol, low density lipoprotein cholesterol, fasting blood glucose, incidence of type 2 diabetes, and systolic and diastolic blood pressure

- Treatment harms: Any adverse events, serious adverse events (requiring admission to hospital or urgent medical care), gastrointestinal events, and withdrawal from the study because of adverse events

Settings

- Generalizable to Canadian primary care or feasible for conducting in or referral from primary care; surgical and metabolic unit interventions were excluded as representing a level of obesity and comorbid conditions that would be less commonly used as referral points from primary care evidence (identified as high, moderate, low or very low quality) was determined using the Grading of Recommendations Assessment, Development and Evaluation (GRADE) framework (GRADEpro version 3.2). ${ }^{15}$ One team member completed full-data abstraction, and a second member verified all extractions. All data were checked in a third round of verification before analysis. Unadjusted immediate postassessment data were extracted where available. For a small number of studies, there were no immediate postassessment data; we chose the data point closest to the end of the intervention. For another small group of ongoing studies, we extracted interim data (at $12 \mathrm{mo}$ ). We extracted data for all reported adverse events. At all levels, inter-rater disagreements were resolved through discussion.

\section{Data analysis}

For meta-analyses, immediate post-treatment data (means and standard deviations) were used for continous outcomes such as weight in $\mathrm{kg}$, whereas number-of-events data were used for binary outcomes such as loss of $\geq 5 \%$ baseline body weight. The DerSimonian and Laird random-effects model with an inverse variance method was used to generate the summary measures of effect in the form of mean difference

\section{Box 2: Inclusion and exclusion criteria}

Studies were included if they met the following criteria:

- Behavioural (diet, exercise or lifestyle strategies), pharmacologic (orlistat or metformin) or combined strategy trial of weight loss treatment or management

- Intervention focused on adults $\geq 18$ years old who were overweight (BMI 25-29.9 kg/m²) or obese (BMI $30-39.9 \mathrm{~kg} / \mathrm{m}^{2}$ )

- Randomized controlled trial with a no-intervention, usual care, placebo or minimal component (e.g., single newsletter or information session on general health) comparison group (this condition applied only to studies assessing treatment effectiveness)

- Reported data for one or more specified weight outcomes (i.e., weight change in $\mathrm{kg}$, loss of $\geq 5 \%$ and $\geq 10 \%$ of baseline body weight, change in waist circumference, and change in BMI)

- Reported data for outcomes of interest at least 12 months postbaseline assessment

- No restrictions on study design, comparison group, reporting of weight outcome or timing of assessment were applied to studies that reported data for harms of treatment

- Results were published in English or French

Studies were excluded if:

- Treatment involved a surgical intervention or a drug other than orlistat or metformin

- Intervention focused on morbidly obese adults (BMI $\left.\geq 40 \mathrm{~kg} / \mathrm{m}^{2}\right)$ or specifically enrolled participants who were pregnant, had an eating disorder or a condition in which weight gain was a cardinal manifestation (e.g., metabolic syndrome or polycystic ovarian disease).

- Intervention was conducted in an inpatient hospital, institutional or occupational setting or involved a school-based or faith-based program

- The only available results were published in a language other than English or French 


\section{OPEN}

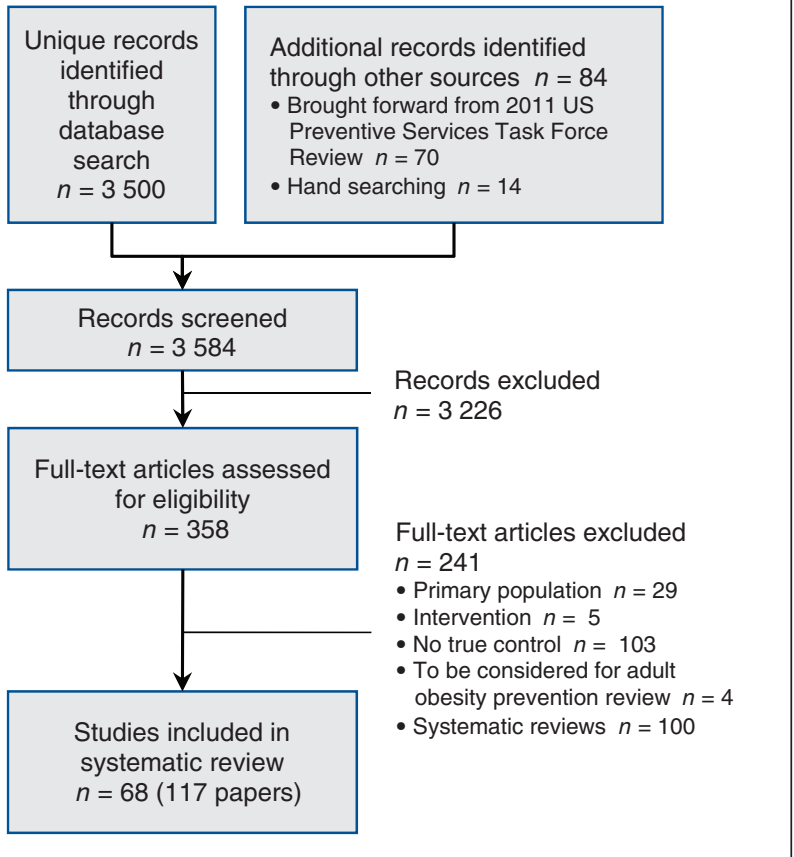

Figure 1: Search and selection flow diagram for articles on treatment of overweight and obesity in adults. for continuous outcomes and risk ratio (RR) for binary outcomes. ${ }^{16}$ For studies with more than one treatment arm, we took different approaches depending on the similarity of the interventions. For similar interventions (e.g., 2 arms of a lifestyle intervention, one using phone contact and one using inperson support) we pooled the data to do a pairwise comparison with the control group. Alternatively, if groups were substantially different (e.g., low-calorie diet and high-intensity aerobic exercise) we included the data for each arm compared with the control group but split the sample size for the control group to avoid a unit-of-analysis error and double counting. ${ }^{14}$ All orlistat studies included an intervention of $120 \mathrm{mg}$ thrice daily. Some studies also assessed smaller doses, but we only extracted data for effects of the consistently reported $120 \mathrm{mg}$ dosage. Cochran's $\mathrm{Q}(\alpha=0.10)$ and $I^{2}$ statistics were used to quantify heterogeneity within and between subgroups. Sensitivity analyses were performed to evaluate statistical stability and effect on statistical heterogeneity. For the outcome of weight in $\mathrm{kg}$, we did subgroup analyses by focus of intervention (behavioural and pharmacologic plus behavioural) for all outcomes and comparisons (except sex for weight in $\mathrm{kg}$ and gastrointestinal adverse effects, which included studies in a single group).

\section{Table 1: Summary of study characteristics}

\begin{tabular}{|c|c|}
\hline Design & - Sixty-eight studies (66 randomized controlled trials, 2 single-group pre-post designs [included for harms outcomes only]) \\
\hline Populations & $\begin{array}{l}\text { - All studies included overweight (body mass index [BMI] } 25-29.9) \text { or obese (BMI 30-39.9) adults } \\
\text { - Two interventions targeted seniors ( } \geq 65 \mathrm{yr} \text { ); all other studies included adults aged } 18 \text { years or older } \\
\text { - Sixty-four studies included both sexes (1 reported data only for men); } 3 \text { included only women, } 1 \text { included only men } \\
\text { - Twenty-six studies (38\%) were directed at populations with a high risk for cardiovascular disease (i.e., screened or } \\
\text { identified as high risk or diagnosed with type } 2 \text { diabetes, hypertension or dyslipidemia) }\end{array}$ \\
\hline Interventions & $\begin{array}{l}\text { - Forty-one behavioural intervention arms ( } 8 \text { diet, } 4 \text { exercise, } 10 \text { diet plus exercise and } 19 \text { lifestyle) in } 39 \text { studies } \\
\text { Twenty-nine pharmacologic ( } 25 \text { studies involved orlistat [dosages: } 23 \text { studies, } 120 \mathrm{mg} \text { three times daily; in } 2 \text { studies, } \\
60 \mathrm{mg} \text { three times daily, included only for harms]; and } 4 \text { studies involved metformin (dosages: } 500 \mathrm{mg} \text { once daily, } \\
850 \mathrm{mg} \text { once daily, } 850 \mathrm{mg} \text { twice daily, } 1500 \mathrm{mg} \text { once daily]) plus behavioural (hypocaloric diet and encouragement to } \\
\text { increase physical activity level) intervention arms in } 27 \text { studies } \\
\text { - Median intervention duration was } 12 \mathrm{mo} ; 49 \text { interventions (72\%) were } \leq 12 \mathrm{mo} ; 19 \text { interventions (28\%) lasted } \\
13-60 \mathrm{mo} \text { : most ran for } \leq 2 \mathrm{yr}\end{array}$ \\
\hline Comp & $\begin{array}{l}\text { - In behavioural intervention trials, control participants received usual care from their physicians or no intervention; in } \\
7 \text { studies they received a minimal component (e.g., printed materials on weight loss and healthy lifestyles) } \\
\text { - In trials using orlistat or metformin, control participants followed the same diet and exercise instructions as the } \\
\text { intervention participants but received placebo instead of active medications }\end{array}$ \\
\hline Outcomes & $\begin{array}{l}\text { - Primary weight outcomes (weight change in kilograms, loss of } \geq 5 \% \text { baseline bodyweight, loss of } \geq 10 \% \text { baseline } \\
\text { body weight, change in BMI and change in waist circumference) } \\
\text { - Secondary health outcomes (total cholesterol, low-density lipoprotein cholesterol level, fasting blood glucose level, } \\
\text { incidence of type } 2 \text { diabetes, systolic blood pressure and diastolic blood pressure) } \\
\text { - Treatment harms (any adverse events, serious adverse events, gastrointestinal events and withdrawal from the study } \\
\text { because of adverse events) }\end{array}$ \\
\hline $\begin{array}{l}\text { Quality } \\
\text { assessment }\end{array}$ & $\begin{array}{l}\text { - Sixty-two of the randomized controlled trials ( } 94 \% \text { ) were rated as having unclear or high risk of bias primarily because } \\
\text { of a lack of information or a lack of procedures to ensure random sequence generation, allocation concealment and } \\
\text { blinding of participants, personnel and outcome assessment } \\
\text { Most outcomes received moderate quality Grading of Recommendations Assessment, Development and Evaluation } \\
\text { ratings (downgraded for risk of bias); occasional low-quality ratings were applied because of added concerns } \\
\text { primarily regarding reporting bias }\end{array}$ \\
\hline Study locations & $\begin{array}{l}\text { - Two studies were conducted in Canada, } 26 \text { in the US, } 31 \text { in European countries, } 1 \text { co-located in the US and Europe, } \\
6 \text { in Australia or New Zealand, } 1 \text { in Japan and } 1 \text { in China }\end{array}$ \\
\hline
\end{tabular}




\section{Results}

The search and selection process is presented in Figure 1. Sixty-eight studies (117 papers) were eligible for inclusion in this review. ${ }^{17-84}$ Thirty-six of these studies were brought forward from the 2011 USPSTF review ${ }^{13}$ that met our inclusion criteria, and 32 studies were found in the recent literature. Of the 68 studies, 54 randomized controlled trials reported weight outcome data that could be pooled; 2 others provided eligible weight data that could not be pooled. ${ }^{51,55}$ The remaining 12 studies (2 studies were single-group pre-post designs, 1 study had a more active comparison group, and 9 studies reported outcomes at $<12 \mathrm{mo}$ ) were only included in analyses of adverse events. ${ }^{24,29,57,63,75-81,83}$ High within-group heterogeneity was common; however, the direction of treatment effect was consistent across most studies, and the confidence intervals overlapped. This statistical heterogeneity is likely due to small versus large treatment effects observed across studies. Table 1 presents a summary of the features of this body of evidence; details for individual studies are provided in Appendix 3 (available at www.cmajopen.ca/content /2/4/E306/suppl/DC1).

\section{Weight outcomes}

Forty-nine studies were included in the meta-analysis assessing weight change in $\mathrm{kg}$. ${ }^{17-23,25-28,31,33-47,49,50,52-54,56,59-61,64-74,82,84}$ Intervention participants had a significantly greater reduction in weight compared with the control group (Table 2 and Figures $2 \mathrm{~A}$ and $2 \mathrm{~B})$. There was no evidence that the effect of treatment differed based on focus of intervention (behavioural or pharmacologic plus behavioural). Weight loss was greater in intervention participants than in control participants for both behavioural interventions and pharmacologic plus behavioural interventions. The test for subgroup differences based on type of behavioural intervention in the behavioural trials (diet, exercise, diet + exercise and lifestyle) was significant: interventions using exercise alone did not lead to significantly greater reductions in weight, whereas diet alone showed the largest difference between groups (Table 2). In the behavioural trials, the test for subgroup differences based on cardiovascular disease risk status was also significant: compared with the control group, changes in weight were greater for participants with low baseline risk than those with high baseline risk (Table 2). There was no evidence that the effect of treatment differed based on any of the other variables considered in the sub-

Table 2: Effect of intervention on weight $(\mathrm{kg})$, by intervention focus and subgroup

\begin{tabular}{|c|c|c|c|c|c|c|c|}
\hline Intervention focus; subgroup & $\begin{array}{l}\text { Meta-analysis, mean } \\
\text { difference }(95 \% \mathrm{Cl})\end{array}$ & $\begin{array}{c}\text { Statistical } \\
\text { heterogeneity } \\
\text { (within group) } \\
p \text { value ( } I^{2} \text { value, \%) }\end{array}$ & $\begin{array}{l}\text { Test for } b \\
\text { group dif } \\
p \text { value }\left(I^{2}\right.\end{array}$ & $\begin{array}{l}\text { between- } \\
\text { ifferences } \\
{ }^{2} \text { value, \%) }\end{array}$ & $\begin{array}{c}\text { No. of } \\
\text { participants }\end{array}$ & $\begin{array}{l}\text { No. of } \\
\text { studies }\end{array}$ & $\begin{array}{c}\text { Quality of } \\
\text { evidence } \\
\text { rating }\end{array}$ \\
\hline Overall & $-3.02(-3.52$ to -2.52$)$ & $<0.00001(91)$ & \multicolumn{2}{|c|}{ NA } & 22615 & 49 & Moderate \\
\hline Behavioural & $-3.13(-3.88$ to -2.38$)$ & $<0.00001(92)$ & \multirow[t]{2}{*}{0.62} & \multirow[t]{2}{*}{$(0)$} & 10829 & 33 & Moderate \\
\hline Pharmacologic + behavioural & $-2.89(-3.49$ to -2.29$)$ & $<0.00001(87)$ & & & 11786 & 17 & Moderate \\
\hline \multicolumn{8}{|l|}{ Behavioural } \\
\hline Diet & $-4.71(-6.22$ to -3.21$)$ & $0.0003 \quad(72)$ & \multirow[t]{4}{*}{0.03} & \multirow[t]{4}{*}{$(67.8)$} & 913 & 8 & Moderate \\
\hline Exercise & $-1.49(-3.32$ to 0.35$)$ & 0.0002 (85) & & & 598 & 4 & Low \\
\hline Diet + exercise & $-3.83(-5.49$ to -2.16$)$ & $<0.00001(90)$ & & & 2382 & 10 & Low \\
\hline Lifestyle & $-2.52(-3.54$ to -1.49$)$ & $<0.00001(93)$ & & & 6936 & 17 & Low \\
\hline$\leq 12$ mo duration & $-3.43(-4.32$ to -2.55$)$ & $<0.00001(88)$ & \multirow[t]{2}{*}{0.07} & \multirow[t]{2}{*}{$(23.4)$} & 4780 & 21 & Low \\
\hline$>12$ mo duration & $-2.53(-3.81$ to -1.24$)$ & $<0.00001(95)$ & & & 6049 & 12 & Low \\
\hline Male & $-4.65(-6.20$ to -3.09$)$ & $<0.00001(89)$ & \multirow[t]{2}{*}{0.23} & \multirow[t]{2}{*}{$(31.5)$} & 2131 & 8 & Moderate \\
\hline Female & $-3.33(-4.80$ to -1.86$)$ & $<0.00001(87)$ & & & 1800 & 8 & Moderate \\
\hline High cardiovascular disease risk & $-1.89(-2.69$ to -1.08$)$ & $<0.00001(75)$ & \multirow[t]{2}{*}{0.005} & \multirow[t]{2}{*}{$(87.6)$} & 2951 & 12 & Low \\
\hline Low cardiovascular disease risk & $-3.66(-4.59$ to -2.74$)$ & $<0.00001(92)$ & & & 7878 & 21 & Moderate \\
\hline \multicolumn{8}{|l|}{ Pharmacologic + behavioural } \\
\hline Metformin & $-1.92(-2.94$ to -0.89$)$ & 0.11 & \multirow[t]{2}{*}{0.07} & \multirow[t]{2}{*}{$(68.8)$} & 1938 & 2 & Moderate \\
\hline Orlistat & $-3.05(-3.75$ to -2.35$)$ & $<0.00001(88)$ & & & 9848 & 15 & Moderate \\
\hline$\leq 12$ mo duration & $-2.89(-3.90$ to -1.88$)$ & $<0.00001(91)$ & \multirow[t]{2}{*}{0.72} & \multirow[t]{2}{*}{$(0)$} & 4418 & 11 & Moderate \\
\hline$>12$ mo duration & $-2.69(-3.00$ to -2.38$)$ & 0.36 & & & 7368 & 6 & Moderate \\
\hline High cardiovascular disease risk & $-2.93(-4.08$ to -1.79$)$ & $<0.00001(92)$ & \multirow[t]{2}{*}{0.80} & \multirow[t]{2}{*}{ (0) } & 3411 & 9 & Moderate \\
\hline Low cardiovascular disease risk & $-2.77(-3.27$ to -2.28$)$ & 0.03 & & & 8375 & 8 & Moderate \\
\hline
\end{tabular}


group tests (i.e., intervention duration, sex, type of drug and cardiovascular disease risk in pharmacologic trials) (Table 2).

Twenty-four studies were included in the meta-analysis assessing loss of $\geq 5 \%$ baseline body weight. ${ }^{17,19,20,27,33,36,38,39}$, 45,53,54,58-60,62,64-68,70,72-74 Figure 3 shows intervention participants were more likely to lose $\geq 5 \%$ of their baseline body weight compared with control participants. There was no evidence that the effect of treatment differed based on focus of intervention (Table 3).
Similarly, 16 studies were included in the meta-analysis assessing loss of $\geq 10 \%$ baseline body weight. ${ }^{19,20,36,58-60,62,64-70,72,74}$ Intervention participants were more likely to lose $\geq 10 \%$ of their baseline body weight compared with controls. There was no evidence that the effect of treatment differed based on focus of intervention (Table 3).

Twenty-six studies were included in the meta-analysis assessing change in BMI from baseline. ${ }^{18-23,25-28,30,32,37,46-50,52-}$ $54,56,61,66,73,84$ Intervention participants had a greater reduction in

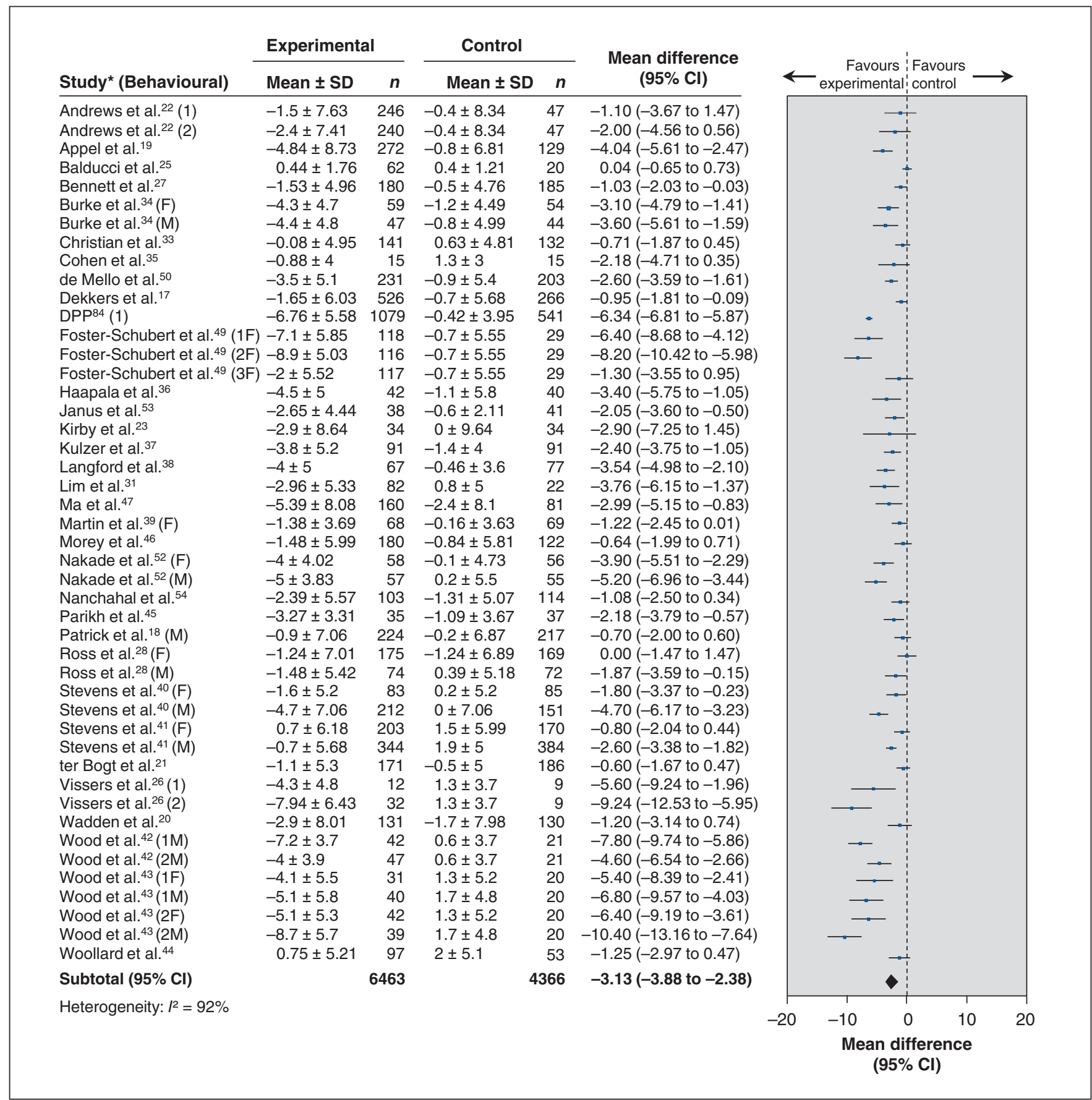

Figure 2A: Effect of behavioural treatment interventions on weight in kilograms. Note: $1=$ intervention arm $1 ; 2=$ intervention arm $2 ; \mathrm{F}=$ females only; $\mathrm{M}=$ males only: $1 \mathrm{~F}, 2 \mathrm{~F}$ and $3 \mathrm{~F}$ represent female participants in different intervention arms; $1 \mathrm{M}$ and $2 \mathrm{M}$ represent male participants in different intervention arms; $\mathrm{Cl}=$ confidence interval; DPP = Diabetes Prevention Program; SD = standard deviation. 
BMI compared with the control groups. There was no evidence that the effect of treatment differed based on focus of intervention (Table 4).

Thirty-three studies were included in the meta-analysis assessing change in waist circumference from baseline. ${ }^{17-22,25,26 \text {, }}$ $28,33,34,36,37,45-47,49,50,52-54,56,58,59,61,65,66,69,71-74,84$ Intervention participants had a greater reduction in waist circumference compared with controls. There was no evidence that the effect of treatment differed based on focus of intervention (Table 4).

\section{Secondary outcomes}

Meta-analyses showed greater improvements in intervention participants compared with control participants across all continuous secondary outcomes: total cholesterol, ${ }^{17,19-23,25,28,31 \text {, }}$ $33,37,42,43,46-48,50,53,56,58,59,61,62,64,65,67-71,73,74,82$ low-density lipoprotein cholesterol, ${ }^{19-23,25,28,31,33,42,43,45-47,53,56,58,59,61,62,64,65,67-71,73,74,82}$ fasting blood glucose, ${ }^{19-22,26,28,31,37,45-48,50,53,56,58,64-72,74,82,84}$ and systolic ${ }^{17,19-}$ $22,25-28,31-34,37,40,42,43,45,47,53,54,58-61,64,66-74,82,84$ and diastolic ${ }^{17,19-22,25-28,31-}$ $34,37,40,42,43,45,47,53,54,58-61,64,66,67,69-74,82,84$ blood pressure (Table 4). For all but 2 of these outcomes, there was no evidence that the effect of treatment differed based on focus of intervention. The tests for subgroup differences were significant for total cholesterol and fasting glucose (Table 4). In both cases, when compared with the control groups, benefits were greater for participants in pharmacologic plus behavioural interventions than for those taking part in behavioural interventions alone.
Nine studies were included in a meta-analysis assessing the risk of type 2 diabetes in prediabetic patients. ${ }^{45-47,50,51,55,72,82,84}$ A diagnosis of new onset type 2 diabetes was less likely to occur in intervention participants compared with the control group (Table 3). There was no evidence that the effect of treatment differed based on focus of intervention (Table 3 ).

\section{Adverse effects}

Very few behavioural studies reported adverse events. When they did, harms were usually minor and related to injuries sustained during physical activity (e.g., joint, back or muscle pain; minor abrasions, bruises or blisters; and fractures). Most (about $80 \%$ ) adverse events that occurred in orlistat trials (and some in metformin trials) were gastrointestinal disturbances. Commonly reported symptoms across studies were fatty or oily stool, increased defecation, increased urgency, abdominal pain, soft stools, oily spotting and flatulence. Most studies reported that the gastrointestinal events were typically mild or moderate in intensity and occurred only once or twice in the participants, usually near the beginning of treatment.

Across the 17 studies with data that could be pooled, intervention participants were more likely to have an adverse event compared with control participants (Table 5). ${ }^{58-61,64,66,67,69-74,82,84}$ However, as indicated by the test for subgroup differences, participants in the 15 pharmacologic interventions were significantly more likely to have an adverse event (Table 5).

\begin{tabular}{|c|c|c|c|c|c|c|c|c|c|}
\hline \multirow[b]{2}{*}{$\begin{array}{l}\text { Study* (Pharmacologic } \\
\text { and behavioural) }\end{array}$} & \multicolumn{2}{|c|}{ Experimental } & \multicolumn{2}{|l|}{ Control } & \multirow[b]{2}{*}{$\begin{array}{c}\text { Mean difference } \\
(95 \% \mathrm{Cl})\end{array}$} & \multirow[b]{2}{*}{$\leftarrow$} & \multirow[b]{2}{*}{$\begin{array}{r}\text { Favours } \\
\text { experimental }\end{array}$} & \multirow[b]{2}{*}{$\begin{array}{l}\text { Favours } \\
\text { control }\end{array}$} & \multirow[b]{2}{*}{$\rightarrow$} \\
\hline & Mean \pm SD & $n$ & Mean \pm SD & $n$ & & & & & \\
\hline Bakris et al. ${ }^{73}$ & $-5.4 \pm 6.4$ & 267 & $-2.7 \pm 6.4$ & 265 & $-2.70(-3.79$ to -1.61$)$ & & - & & \\
\hline Broom et al. ${ }^{59}$ & $-5.8 \pm 8.5$ & 259 & $-2.3 \pm 6.4$ & 263 & $-3.50(-4.79$ to -2.21$)$ & & - & & \\
\hline Davidson et al. ${ }^{60}$ & $-8.76 \pm 9.48$ & 657 & $-5.81 \pm 10.01$ & 223 & $-2.95(-4.45$ to -1.45$)$ & & $\rightarrow$ & & \\
\hline Derosa et al. ${ }^{61}$ & $-8.6 \pm 1$ & 25 & $-7.6 \pm 0.7$ & 23 & $-1.00(-1.49$ to -0.51$)$ & & ' & & \\
\hline Derosa et al. ${ }^{56}$ & $-9.5 \pm 5$ & 113 & $-2.6 \pm 3.79$ & 121 & $-6.90(-8.04$ to -5.76$)$ & & - & & \\
\hline $\operatorname{DPP}^{84}(2)$ & $-2.72 \pm 5.57$ & 1073 & $-0.42 \pm 3.95$ & 541 & $-2.30(-2.77$ to -1.83$)$ & & $=$ & & \\
\hline Fontbonne et al. 82 & $-2 \pm 6.21$ & 164 & $-0.8 \pm 5.49$ & 160 & $-1.20(-2.48$ to 0.08$)$ & & - & & \\
\hline Hauptman et al. ${ }^{64}$ & $-7.94 \pm 8.26$ & 210 & $-4.14 \pm 8.15$ & 212 & $-3.80(-5.37$ to -2.23$)$ & & $\rightarrow$ & & \\
\hline Hollander et al. ${ }^{65}$ & $-6.19 \pm 6.49$ & 162 & $-4.31 \pm 7.19$ & 159 & $-1.88(-3.38$ to -0.38$)$ & & $\rightarrow$ & & \\
\hline Kelley et al. ${ }^{74}$ & $-3.89 \pm 4.4$ & 266 & $-1.27 \pm 4.59$ & 269 & $-2.62(-3.38$ to -1.86$)$ & & -1 & & \\
\hline Krempf et al. ${ }^{66}$ & $-5.3 \pm 9.3$ & 346 & $-2.4 \pm 9.35$ & 350 & $-2.90(-4.29$ to -1.51$)$ & & $\rightarrow$ & & \\
\hline Lindgärde 67 & $-5.6 \pm 5.2$ & 190 & $-4.3 \pm 5.9$ & 186 & $-1.30(-2.43$ to -0.18$)$ & & '؛ & & \\
\hline Miles et al. 68 & $-4.7 \pm 4.74$ & 250 & $-1.8 \pm 4.78$ & 254 & $-2.90(-3.73$ to -2.07$)$ & & - & & \\
\hline Rossner et al. 69 & $-7.4 \pm 7.1$ & 242 & $-4.3 \pm 7.4$ & 237 & $-3.10(-4.40$ to -1.80$)$ & & $=$ & & \\
\hline Sjöström et al. ${ }^{70}$ & $-10.3 \pm 9.3$ & 343 & $-6.1 \pm 9.3$ & 340 & $-4.20(-5.59$ to -2.81$)$ & & $\rightarrow$ & & \\
\hline Swinburn et al. ${ }^{71}$ & $-4.7 \pm 7.7$ & 170 & $-0.9 \pm 4.2$ & 169 & $-3.80(-5.12$ to -2.48$)$ & & $\rightarrow$ & & \\
\hline Torgerson et al. ${ }^{72}$ & $-5.8 \pm 5.58$ & 1640 & $-3 \pm 5.58$ & 1637 & $-2.80(-3.18$ to -2.42$)$ & & - & & \\
\hline Subtotal $(95 \% \mathrm{Cl})$ & & 6377 & & 5409 & $-2.89(-3.49$ to -2.29$)$ & & $\downarrow$ & & \\
\hline \multicolumn{10}{|l|}{ Heterogeneity: $I^{2}=87 \%$} \\
\hline \multirow{2}{*}{$\begin{array}{l}\text { Total }(\mathbf{9 5} \% \mathrm{Cl}) \\
\text { Heterogeneity: } I^{2}=91 \% \\
\text { Test for subgroup difference }\end{array}$} & & 12840 & & 9775 & $-3.02(-3.52$ to -2.52$)$ & & $\downarrow$ & & \\
\hline & ces: $/^{2}=0 \%$ & & & & & -20 & -10 & 10 & 20 \\
\hline & & & & & & \multicolumn{4}{|c|}{$\begin{array}{l}\text { Mean difference } \\
(95 \% \mathrm{Cl})\end{array}$} \\
\hline
\end{tabular}

Figure 2B: Effect of pharmacologic plus behavioural treatment interventions on weight in kilograms. Note: $2=$ intervention arm 2; $\mathrm{Cl}=$ confidence interval; DPP = Diabetes Prevention Program; SD = standard deviation. 
Serious adverse events were defined as those requiring urgent medical care or admission to hospital, as well as those defined as serious by the primary authors. A meta-analysis of 14 studies showed no difference between the intervention and control groups for the risk of having serious adverse events, and there was no evidence that the effect of treatment differed based on focus of intervention (Table 5). ${ }^{20,27,57,59,61,66,67,70-73,77,79,84}$ Gastrointestinal events were reported only in studies that used drug interventions and in the 23 studies with data that could be pooled; those taking active medications were more likely to report these events than control participants. ${ }^{57,59,61-69,71-77,79,81-84}$ Likewise, participants in 25 pharmacologic studies were more likely to withdraw from their study because of adverse events compared with control participants (Table 5). ${ }^{46,56,58-77,79,81,82}$

\section{Interpretation}

\section{Main findings}

There are 3 principal findings from this review. First, the pooled-effect estimates for all weight outcomes were statistically significant in favour of the interventions and, compared with the control groups, intervention participants had, on average, a $3.02 \mathrm{~kg}$ greater weight loss, a $2.78 \mathrm{~cm}$ greater reduction in waist circumference, and a $1.11 \mathrm{~kg} / \mathrm{m}^{2}$ greater reduction in $\mathrm{BMI}$, and were more likely to lose $\geq 5 \%$ (RR 1.77 ) and $\geq 10 \%$ (RR 1.91) of their baseline body weight. Every kilogram of weight loss in people with impaired glucose tolerance is associated with a $16 \%$ reduction in the incidence of type 2 diabetes. ${ }^{85}$ Second, there was no significant difference

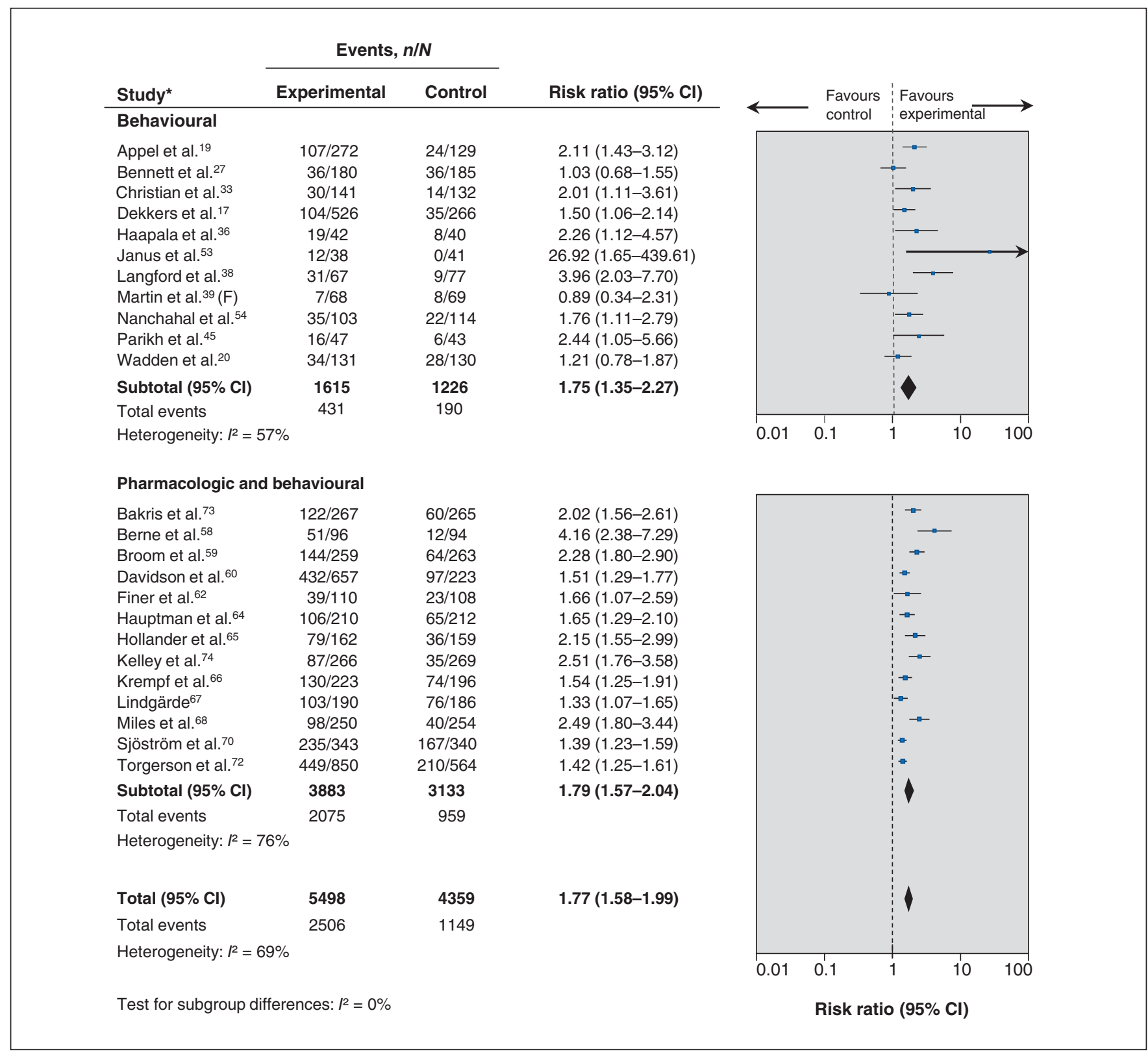

Figure 3: Effect of treatment interventions on loss of $\geq 5 \%$ baseline body weight: overall and by focus of intervention (behavioural and pharmacologic plus behavioural). Note: $\mathrm{Cl}=$ confidence interval; $\mathrm{F}=$ females only. 
between behavioural and pharmacologic interventions for any weight outcomes, although the potential for adverse outcomes appears greater with pharmacologic treatments. Third, modest weight reduction, corresponding to loss of $\geq 5 \%$ and $\geq 10 \%$ of baseline body weight (number needed to treat 5 and 9 , respectively) had clinically important effects, most notably a $38 \%$ reduction in the incidence of type 2 diabetes in prediabetic populations (number needed to treat 17 ). With prevalence rates for type 2 diabetes in the US and the European Union of $9.3 \%$ and $10 \%$, respectively ${ }^{86}$ coupled with its increasing prevalence, extrapolation of a $38 \%$ reduction in the incidence of type 2 diabetes could have a significant benefit on population health. Intervention participants also had small improvements in secondary outcomes; these effects may be of minor clinical significance at the individual level, but important at the population level.

The benefits of treatment should be weighed against the harms. Few behavioural studies reported adverse events; those that did found a small absolute excess in the risk of injuries associated with physical activity. Participants on active medications reported significantly milder to moderate gastrointestinal disturbances than those on placebo.

\section{Comparison with other studies}

Updating the United States Preventive Services Task Force review search ${ }^{13}$ added 32 studies, but did not point to changes in any important outcomes. We used a more comprehensive approach of subgrouping studies based on behavioural interventions such diet, exercise and lifestyle changes to better reflect the evidence in the current literature. In addition to a modest reduction observed for measures of adiposity such as weight in kilograms, BMI and waist circumference, our review also found associated reductions in intermediate physiological outcomes such as blood pressure and incidence of type 2 diabetes, which reinforces the findings of other systematic reviews ${ }^{87,88,89}$ documenting reduction in the need for pharmacologic therapy for blood pressure and glycemic control as a potential clinical benefit of modest weight loss.

\section{Limitations}

Most evidence was derived from studies that could not be assessed comprehensively for risk of bias. Two-thirds of the pharmacologic studies had prerandomization run-in periods that involved low-calorie diets with or without placebo, which may have exaggerated the potential benefits of treatment. Potential reporting bias was identified across a number of outcome and comparison-based study groupings. The relatively high attrition rates in many studies leads to further risk of bias. These methodological limitations reduced the strength of evidence, resulting in moderateand sometimes low-quality ratings, which reduce confidence in the pooled estimates of effect. Results presented for the secondary outcomes should be interpreted with caution because we only included interventions where the focus was on weight loss. Adverse events may be overestimated; data were extracted as reported even when the connection to the intervention was not clear and even if run-in events were included. The search included papers in English or French only and thus may have missed studies in other languages. Most studies were of relatively short duration $(\leq 12 \mathrm{mo})$, and there was a lack of evidence to address the question of whether (and for how long) weight loss is maintained after interventions are completed.

Table 3: Effect of intervention on weight loss and diabetes outcomes, by intervention focus

\begin{tabular}{|c|c|c|c|c|c|c|c|c|}
\hline \multirow[b]{2}{*}{ Outcome; intervention focus } & \multicolumn{3}{|c|}{ Effect on $\%$ weight loss } & \multirow{2}{*}{$\begin{array}{c}\text { Statistical } \\
\text { heterogeneity } \\
\text { (within group) } \\
p \text { value } \\
\left(R^{2} \text { value, } \%\right)\end{array}$} & \multirow{2}{*}{$\begin{array}{c}\text { Test for between- } \\
\text { group differences } \\
p \text { value } \\
\left(I^{2} \text { value, } \%\right)\end{array}$} & \multirow[b]{2}{*}{$\begin{array}{c}\text { No. of } \\
\text { participants }\end{array}$} & \multirow[b]{2}{*}{$\begin{array}{l}\text { No. of } \\
\text { studies }\end{array}$} & \multirow[b]{2}{*}{$\begin{array}{c}\text { Quality o } \\
\text { evidence } \\
\text { rating }\end{array}$} \\
\hline & $\mathrm{RR}(95 \% \mathrm{Cl})$ & $\begin{array}{l}\text { Absolute risk } \\
\text { reduction, \% }\end{array}$ & $\begin{array}{l}\text { No. needed } \\
\text { to treat } \\
(95 \% \mathrm{Cl})\end{array}$ & & & & & \\
\hline \multicolumn{9}{|c|}{ Loss of $\geq 5 \%$ baseline body weight } \\
\hline Overall & $1.77(1.58-1.99)$ & 20.42 & $5(4-7)$ & $<0.00001(69)$ & NA & 9857 & 24 & Low \\
\hline Behavioural & $1.75(1.35-2.27)$ & 11.67 & $9(5-18)$ & $(57)$ & $0.88(0)$ & 2841 & 11 & Low \\
\hline Pharmacologic + behavioural & $1.79(1.57-2.04)$ & 24.26 & $4(3-6)$ & $<0.00001(76)$ & & 7016 & 13 & Low \\
\hline \multicolumn{9}{|c|}{ Loss of $\geq 10 \%$ baseline body weight } \\
\hline Overall & $1.91(1.69-2.16)$ & 11.24 & $9(7-12)$ & $(16)$ & NA & 7523 & 16 & Low \\
\hline Behavioural & $2.04(1.30-3.21)$ & 8.01 & $12(6-44)$ & 0.81 & $0.81(0)$ & 744 & 3 & Moderate \\
\hline Pharmacologic + behavioural & $1.92(1.67-2.21)$ & 11.81 & $8(6-12)$ & (31) & & 6779 & 13 & Low \\
\hline \multicolumn{9}{|l|}{ Incidence of type 2 diabetes } \\
\hline Overall & $0.62(0.50-0.77)$ & 5.75 & $17(13-29)$ & $(54)$ & NA & 8624 & 9 & Moderate \\
\hline Behavioural & $0.55(0.42-0.72)$ & 8.88 & $11(9-18)$ & (23) & $0.11(60)$ & 3198 & 7 & Moderate \\
\hline Pharmacologic + behavioural & $0.72(0.59-0.87)$ & 3.60 & $28(19-60)$ & $0.26 \quad(27)$ & & 5426 & 3 & Moderate \\
\hline
\end{tabular}




\section{Conclusion}

In summary, modest weight reduction confers clinically important benefits and a substantial reduction in the incidence of type 2 diabetes in prediabetic populations, with the potential to improve population health. Future research should include longer term follow-up to observe maintenance of weight loss, to study the effects of repeated weight loss and regain, and to determine if improvements in health outcomes are related to the intervention apart from weight loss.

\section{References}

1. Obesity and overweight. Geneva (Switzerland): World Health Organization; 2014. Available: www.who.int/mediacentre/factsheets/fs311/en/ (accessed 2014 Sept. 17).
2. Eckersley RM. Losing the battle of the bulge: causes and consequences of increasing obesity. Med 7 Aust 2001;174:590-2.

3. Mokdad AH, Ford ES, Bowman BA, et al. Prevalence of obesity, diabetes, and obesity-related health risk factors, 2001. FAMA 2003;289:76-9.

4. Wilson PW, D'Agostino RB, Sullivan L, et al. Overweight and obesity as determinants of cardiovascular risk: the Framingham experience. Arch Intern Med 2002;162:1867-72.

5. Flegal KM, Graubard BI, Williamson DF, et al. Excess deaths associated with underweight, overweight, and obesity. FAMA 2005;293:1861-7.

6. Allison DB, Fontaine KR, Manson JE, et al. Annual deaths attributable to obesity in the United States. FAMA 1999;282:1530-8.

7. Castañeda-Gonzalez L, Camberos-Solís R, Bacardi-Gascón M, et al. Long-term randomized clinical trials of pharmacological treatment of obesity: systematic review. Colomb Med 2010;41:17-25.

8. Felix HC, West DS. Effectiveness of weight loss interventions for obese older adults. Am 7 Health Promot 2013;27:191-9.

9. Aucott L, Gray D, Rothnie H, et al. Effects of lifestyle interventions and longterm weight loss on lipid outcomes - a systematic review. Obes Rev 2011; $12: \mathrm{e} 412-25$

Table 4: Effect of intervention on body mass index, waist circumference and secondary health outcomes, by intervention focus

\begin{tabular}{|c|c|c|c|c|c|c|c|}
\hline Outcome; intervention focus & $\begin{array}{l}\text { Meta-analysis, mean } \\
\text { difference }(95 \% \mathrm{Cl})\end{array}$ & $\begin{array}{r}\text { Statistical he } \\
\text { (within } g \\
p \text { value }\left(I^{2}\right.\end{array}$ & $\begin{array}{l}\text { erogeneity } \\
\text { roup) } \\
\text { alue, \%) }\end{array}$ & $\begin{array}{c}\text { Test for between- } \\
\text { group differences } \\
p \text { value }\left(I^{2} \text { value, } \%\right)\end{array}$ & $\begin{array}{c}\text { No. of } \\
\text { participants }\end{array}$ & $\begin{array}{l}\text { No. of } \\
\text { studies }\end{array}$ & $\begin{array}{l}\text { Quality of } \\
\text { evidence } \\
\text { rating }\end{array}$ \\
\hline \multicolumn{8}{|l|}{ Primary weight outcomes } \\
\hline \multicolumn{8}{|l|}{ Body mass index, $\mathrm{kg} / \mathrm{m}^{2}$} \\
\hline Overall & $-1.11(-1.39$ to -0.84$)$ & $<0.00001$ & (93) & NA & 10611 & 26 & Moderate \\
\hline Behavioural & $-1.09(-1.43$ to -0.75$)$ & $<0.00001$ & $(93)$ & \multirow[t]{2}{*}{$0.59 \quad(0)$} & 7487 & 22 & Moderate \\
\hline Pharmacologic + behavioural & $-1.27(-1.82$ to -0.72$)$ & $<0.00001$ & (93) & & 3124 & 5 & Moderate \\
\hline \multicolumn{8}{|l|}{ Waist circumference, $\mathrm{cm}$} \\
\hline Overall & $-2.78(-3.34$ to -2.22$)$ & $<0.00001$ & $(91)$ & \multirow{3}{*}{$\begin{array}{r}\text { NA } \\
18 \quad(44\end{array}$} & 16565 & 33 & Moderate \\
\hline Behavioural & $-3.05(-3.86$ to -2.24$)$ & $<0.00001$ & $(90)$ & & 7770 & 22 & Moderate \\
\hline Pharmacologic + behavioural & $-2.29(-3.04$ to -1.55$)$ & $<0.00001$ & (91) & & 8795 & 12 & Moderate \\
\hline \multicolumn{8}{|l|}{ Secondary health outcomes } \\
\hline \multicolumn{8}{|l|}{ Total cholesterol, $\mathrm{mmol} / \mathrm{L}$} \\
\hline Overall & $-0.21(-0.29$ to -0.13$)$ & $<0.00001$ & $(86)$ & NA & 10039 & 33 & Moderate \\
\hline Behavioural & $-0.10(-0.18$ to -0.03$)$ & $<0.0001$ & (63) & \multirow[t]{2}{*}{$0.0001(93.1)$} & 4282 & 18 & Low \\
\hline Pharmacologic + behavioural & $-0.33(-0.42$ to -0.24$)$ & $<0.00001$ & $(81)$ & & 5757 & 15 & Moderate \\
\hline \multicolumn{8}{|c|}{ Low-density lipoprotein cholesterol, mmol/L } \\
\hline Overall & $-0.21(-0.29$ to -0.12$)$ & $<0.00001$ & $(90)$ & NA & 9313 & 30 & Low \\
\hline Behavioural & $-0.14(-0.29$ to -0.002$)$ & $<0.00001$ & (90) & \multirow[t]{2}{*}{$0.11 \quad(60.1)$} & 3556 & 15 & Moderate \\
\hline Pharmacologic + behavioural & $-0.28(-0.38$ to -0.19$)$ & $<0.00001$ & $(89)$ & & 5757 & 15 & Moderate \\
\hline \multicolumn{8}{|l|}{ Fasting blood glucose, $\mathrm{mmol} / \mathrm{L}$} \\
\hline Overall & $-0.26(-0.38$ to -0.13$)$ & $<0.00001$ & (96) & NA & 12646 & 28 & Moderate \\
\hline Behavioural & $-0.14(-0.23$ to -0.05$)$ & $<0.00001$ & $(81)$ & \multirow[t]{2}{*}{$0.02(80.7)$} & 5106 & 15 & Moderate \\
\hline Pharmacologic + behavioural & $-0.43(-0.66$ to -0.20$)$ & $<0.00001$ & (98) & & 7540 & 14 & Moderate \\
\hline \multicolumn{8}{|l|}{ Systolic blood pressure, $\mathrm{mm} \mathrm{Hg}$} \\
\hline Overall & $-1.70(-2.23$ to -1.17$)$ & 0.002 & (41) & NA & 16668 & 37 & Moderate \\
\hline Behavioural & $-1.76(-2.61$ to -0.91$)$ & 0.0009 & $(50)$ & \multirow[t]{2}{*}{$0.91 \quad(0)$} & 7644 & 22 & Moderate \\
\hline Pharmacologic + behavioural & $-1.70(-2.28$ to -1.13$)$ & 0.24 & (19) & & 9024 & 16 & Moderate \\
\hline \multicolumn{8}{|l|}{ Diastolic blood pressure, $\mathrm{mm} \mathrm{Hg}$} \\
\hline Overall & $-1.42(-1.88$ to -0.96$)$ & $<0.00001$ & (63) & NA & 16158 & 36 & Moderate \\
\hline Behavioural & $-1.60(-2.27$ to -0.93$)$ & $<0.00001$ & (63) & \multirow[t]{2}{*}{$0.45 \quad(0)$} & 7690 & 22 & Moderate \\
\hline Pharmacologic + behavioural & $-1.24(-1.88$ to -0.61$)$ & 0.0002 & (65) & & 8468 & 15 & Moderate \\
\hline
\end{tabular}


Table 5: Effect of intervention on any adverse events, serious adverse events, gastrointestinal events and withdrawals from the study because of adverse events, by intervention focus

\begin{tabular}{|c|c|c|c|c|c|c|c|c|}
\hline \multirow[b]{2}{*}{ Outcome; intervention focus } & \multicolumn{3}{|c|}{ Effect } & \multirow{2}{*}{$\begin{array}{c}\text { Statistical } \\
\text { heterogeneity } \\
\text { (within group) } \\
p \text { value } \\
\left(R^{2} \text { value, } \%\right)\end{array}$} & \multirow{2}{*}{$\begin{array}{c}\text { Test for between- } \\
\text { group differences } \\
p \text { value } \\
\left(R^{2} \text { value, } \%\right)\end{array}$} & \multirow[b]{2}{*}{$\begin{array}{c}\text { No. of } \\
\text { participants }\end{array}$} & \multirow[b]{2}{*}{$\begin{array}{l}\text { No. of } \\
\text { studies }\end{array}$} & \multirow[b]{2}{*}{$\begin{array}{c}\text { Quality of } \\
\text { evidence } \\
\text { rating }\end{array}$} \\
\hline & $\mathrm{RR}(95 \% \mathrm{Cl})$ & $\begin{array}{l}\text { Absolute risk } \\
\text { increase, \% }\end{array}$ & $\begin{array}{l}\text { No. needed } \\
\text { to harm } \\
(95 \% \mathrm{Cl})\end{array}$ & & & & & \\
\hline \multicolumn{9}{|l|}{ Any adverse events } \\
\hline Overall & $1.16(1.09-1.23)$ & 9.31 & $11(7-19)$ & $<0.00001(73)$ & NA & 5512 & 17 & Moderate \\
\hline Behavioural & $0.19(0.03-1.16)$ & - & - & $0.41 \quad(0)$ & \multirow[t]{2}{*}{$0.05(74)$} & 561 & 3 & Low \\
\hline Pharmacological + behavioural & $1.16(1.09-1.23)$ & 10.36 & $10(7-17)$ & $<0.00001(75)$ & & 4951 & 15 & Moderate \\
\hline \multicolumn{9}{|l|}{ Serious adverse events } \\
\hline Overall & $1.07(0.96-1.20)$ & - & - & $0.74 \quad(0)$ & NA & 10811 & 14 & Low \\
\hline Behavioural & $0.995(0.80-1.24)$ & - & - & $0.68 \quad(0)$ & \multirow[t]{2}{*}{$0.44(0)$} & 2174 & 3 & Low \\
\hline Pharmacological + behavioural & $1.10(0.97-1.25)$ & - & - & $0.62(0)$ & & 8637 & 12 & Low \\
\hline \multicolumn{9}{|l|}{ Gastrointestinal events } \\
\hline Pharmacological + behavioural & $1.58(1.47-1.70)$ & 18.72 & $5(4-7)$ & $<0.00001(71)$ & NA & 12954 & 23 & Low \\
\hline \multicolumn{9}{|c|}{ Study withdrawal because of adverse events } \\
\hline Overall & $1.69(1.43-2.00)$ & 3.05 & $33(23-53)$ & $0.65(0)$ & NA & 12987 & 26 & Moderate \\
\hline Behavioural & $3.40(0.16-70.16)$ & - & - & NA & $0.65(0)$ & 302 & 1 & Low \\
\hline Pharmacological + behavioural & $1.68(1.42-2.00)$ & 3.09 & $32(22-47)$ & $0.25(15)$ & & 12685 & 25 & Moderate \\
\hline
\end{tabular}

10. Santos FL, Esteves SS, da Costa PA, et al. Systematic review and meta-analysis of clinical trials of the effects of low carbohydrate diets on cardiovascular risk factors. Obes Rev 2012;13:1048-66.

11. Kelley GA, Kelley KS, Roberts S, et al. Combined effects of aerobic exercise and diet on lipids and lipoproteins in overweight and obese adults: a metaanalysis. 7 Obes 2012;2012: 985902.

12. Shea BJ, Grimshaw JM, Wells GA, et al. Development of AMSTAR: a measurement tool to assess the methodological quality of systematic reviews. BMC Med Res Methodol 2007;7:10.

13. LeBlanc, E, O'Connor, E, Whitlock, EP, et al. Screening for and management of obesity and overweight in adults. Rockville (MD): Agency for Healthcare Research and Quality; 2011. Report no.:11-05159-EF-1.

14. Cochrane handbook for systematic reviews of interventions. Version 5.1.0. New York: John Wiley \& Sons; 2011.

15. Grading of Recommendations Assessment, Development and Evaluation (GRADE) Working Group. 2000. Introduction. Available: www.gradeworkinggroup.org/.

16. DerSimonian R, Laird N. Meta-analysis in clinical trials. Control Clin Trials 1986; 7:177-88

17. Dekkers JC, van Wier MF, Ariëns GA, et al. Comparative effectiveness of lifestyle interventions on cardiovascular risk factors among a Dutch overweight working population: a randomized controlled trial. BMC Public Health 2011;11:49

18. Patrick K, Calfas KJ, Norman GJ, et al. Outcomes of a 12-month web-based intervention for overweight and obese men. Ann Behav Med 2011;42:391-401.

19. Appel LJ, Clark JM, Yeh HC, et al. Comparative effectiveness of weight-loss interventions in clinical practice. N Engl 7 Med 2011;365:1959-68.

20. Wadden TA, Volger S, Sarwer DB, et al. A two-year randomized trial of obesity treatment in primary care practice. N Engl 7 Med 2011;365:1969-79.

21. ter Bogt NC, Milder IE, Bemelmans WJ, et al. Changes in lifestyle habits after counselling by nurse practitioners: 1-year results of the Groningen Overweight and Lifestyle study. Public Health Nutr 2011;14:995-1000.

22. Andrews RC, Cooper AR, Montgomery AA, et al. Diet or diet plus physical activity versus usual care in patients with newly diagnosed type 2 diabetes: the Early ACTID randomised controlled trial. Lancet 2011;378:129-39.

23. Kirby ML, Beatty S, Stack J, et al. Changes in macular pigment optical density and serum concentrations of lutein and zeaxanthin in response to weight loss. Br 7 Nutr 2011;105:1036-46.

24. Tsai AG, Wadden TA, Rogers MA, et al. A primary care intervention for weight loss: results of a randomized controlled pilot study. Obesity (Silver Spring) 2010;18:1614-8

25. Balducci S, Zanuso S, Nicolucci A, et al. Anti-inflammatory effect of exercise training in subjects with type 2 diabetes and the metabolic syndrome is dependent on exercise modalities and independent of weight loss. Nutr Metab Cardiovasc Dis 2010;20:608-17.
26. Vissers D, Verrijken A, Mertens I, et al. Effect of long-term whole body vibration training on visceral adipose tissue: a preliminary report. Obes Facts 2010; 3:93-100.

27. Bennett GG, Warner ET, Glasgow RE, et al. Obesity treatment for socioeconomically disadvantaged patients in primary care practice. Arch Intern Med 2012;172:565-74.

28. Ross R, Lam M, Blair SN, et al. Trial of prevention and reduction of obesity through active living in clinical settings: a randomized controlled trial. Arch Intern Med 2012;172:414-24.

29. Donner TW, Magder LS, Zarbalian K. Dietary supplementation with D-tagatose in subjects with type 2 diabetes leads to weight loss and raises high-density lipoprotein cholesterol. Nutr Res 2010;30:801-6.

30. Janney CA, Jakicic JM. The influence of exercise and BMI on injuries and illnesses in overweight and obese individuals: a randomized control trial. Int 7 Behav Nutr Phys Act 2010;7:1

31. Lim SS, Noakes M, Keogh JB, et al. Long-term effects of a low carbohydrate, low fat or high unsaturated fat diet compared to a no-intervention control. Nutr Metab Cardiovasc Dis 2010;20:599-607.

32. Anderssen S, Holme I, Urdal P, et al. Diet and exercise intervention have favourable effects on blood pressure in mild hypertensives: the Oslo Diet and Exercise Study (ODES). Blood Press 1995;4:343-9.

33. Christian JG, Bessesen DH, Byers TE, et al. Clinic-based support to help overweight patients with type 2 diabetes increase physical activity and lose weight. Arch Intern Med 2008;168:141-6.

34. Burke V, Beilin LJ, Cutt HE, et al. Effects of a lifestyle programme on ambulatory blood pressure and drug dosage in treated hypertensive patients: a randomized controlled trial. 7 Hypertens 2005;23:1241-9.

35. Cohen MD, D'Amico FJ, Merenstein JH. Weight reduction in obese hypertensive patients. Fam Med 1991;23:25-8.

36. Haapala I, Barengo NC, Biggs S, et al. Weight loss by mobile phone: a 1-year effectiveness study. Public Health Nutr 2009;12:2382-91.

37. Kulzer B, Hermanns N, Gorges D, et al. Prevention of diabetes selfmanagement program (PREDIAS): effects on weight, metabolic risk factors, and behavioral outcomes. Diabetes Care 2009;32:1143-6.

38. Langford HG, Blaufox MD, Oberman A, et al. Dietary therapy slows the return of hypertension after stopping prolonged medication. $7 A M A$ 1985;253:657-64

39. Martin PD, Dutton GR, Rhode PC, et al. Weight loss maintenance following a primary care intervention for low-income minority women. Obesity (Silver Spring) 2008;16:2462-7.

40. Stevens VJ, Corrigan SA, Obarzanek E, et al. Weight loss intervention in phase 1 of the Trials of Hypertension Prevention. The TOHP Collaborative Research Group. Arch Intern Med 1993;153:849-58. 
41. Stevens VJ, Obarzanek E, Cook NR, et al. Long-term weight loss and changes in blood pressure: results of the Trials of Hypertension Prevention, phase II. Ann Intern Med 2001;134:1-11.

42. Wood PD, Stefanick ML, Dreon DM, et al. Changes in plasma lipids and lipoproteins in overweight men during weight loss through dieting as compared with exercise. NEngl 7 Med 1988;319:1173-9.

43. Wood PD, Stefanick ML, Williams PT, et al. The effects on plasma lipoproteins of a prudent weight-reducing diet, with or without exercise, in overweight men and women. N Engl 7 Med 1991;325:461-6.

44. Woollard J, Burke V, Beilin LJ, et al. Effects of a general practice-based intervention on diet, body mass index and blood lipids in patients at cardiovascular risk. 7 Cardiovasc Risk 2003;10:31-40.

45. Parikh P, Simon EP, Fei K, et al. Results of a pilot diabetes prevention intervention in East Harlem, New York City: Project HEED. Am 7 Public Health 2010;100(Suppl 1):S232-9.

46. Morey MC, Pieper CF, Edelman DE, et al. Enhanced fitness: a randomized controlled trial of the effects of home-based physical activity counseling on glycemic control in older adults with prediabetes mellitus. 7 Am Geriatr Soc 2012;60:1655-62.

47. Ma J, Yank V, Xiao L, et al. Translating the Diabetes Prevention Program lifestyle intervention for weight loss into primary care: a randomized trial. $7 A M A$ Intern Med 2013;173:113-21.

48. Burtscher M, Gatterer H, Dünnwald T, et al. Effects of supervised exercise on gamma-glutamyl transferase levels in patients with isolated impaired fasting glucose and those with impaired fasting glucose plus impaired glucose tolerance. Exp Clin Endocrinol Diabetes 2012;120:445-50.

49. Foster-Schubert KE, Alfano CM, Duggan CR, et al. Effect of diet and exercise, alone or combined, on weight and body composition in overweight-to-obese postmenopausal women. Obesity (Silver Spring) 2012;20:1628-38.

50. de Mello VD, Lindström J, Eriksson J, et al. Insulin secretion and its determinants in the progression of impaired glucose tolerance to type 2 diabetes in impaired glucose-tolerant individuals: the Finnish Diabetes Prevention Study. Diabetes Care 2012;35:211-7.

51. Ockene IS, Tellez TL, Rosal MC, et al. Outcomes of a Latino communitybased intervention for the prevention of diabetes: the Lawrence Latino Diabetes Prevention Project. Am 7 Public Health 2012;102:336-42.

52. Nakade M, Aiba N, Suda N, et al. Behavioral change during weight loss program and one-year follow-up: Saku Control Obesity Program (SCOP) in Japan. Asia Pac 7 Clin Nutr 2012;21:22-34.

53. Janus ED, Best JD, Davis-Lameloise N, et al. Scaling-up from an implementation trial to state-wide coverage: results from the preliminary Melbourne Diabetes Prevention Study. Trials 2012;13:152

54. Nanchahal K, Power T, Holdsworth E, et al. A pragmatic randomised controlled trial in primary care of the Camden Weight Loss (CAMWEL) programme. BMF Open 2012;2:e00793.

55. Penn L, White M, Oldroyd J, et al. Prevention of type 2 diabetes in adults with impaired glucose tolerance: the European Diabetes Prevention RCT in Newcastle upon Tyne, UK. BMC Public Health 2009;9:342.

56. Derosa G, Cicero AF, D'Angelo A, et al. Effects of 1-year orlistat treatment compared to placebo on insulin resistance parameters in patients with type 2 diabetes. 7 Clin Pharm Ther 2012;37:187-95.

57. Kopelman P, Groot GH, Rissanen A, et al. Weight loss, HbAlc reduction, and tolerability of cetilistat in a randomized, placebo-controlled phase 2 trial in obese diabetics: comparison with orlistat (Xenical). Obesity (Silver Spring) 2010;18:108-15.

58. Berne C; Orilstat Swedish Type 2 Diabetes Study Group. A randomized study of orlistat in combination with a weight management programme in obese patients with type 2 diabetes treated with metformin. Diabet Med 2005; 22:612-8.

59. Broom I, Wilding J, Stott P, et al.; UK Multimorbidity Study Group. Randomised trial of the effect of orlistat on body weight and cardiovascular disease risk profile in obese patients: UK Multimorbidity Study. Int 7 Clin Pract 2002;56:494-9.

60. Davidson MH, Hauptman J, DiGirolamo M, et al. Weight control and risk factor reduction in obese subjects treated for 2 years with orlistat: a randomized controlled trial. FAMA 1999;281:235-42.

61. Derosa G, Mugellini A, Ciccarelli L, et al. Randomized, double-blind, placebocontrolled comparison of the action of orlistat, fluvastatin, or both an anthropometric measurements, blood pressure, and lipid profile in obese patients with hypercholesterolemia prescribed a standardized diet. Clin Ther 2003;25: 1107-22.

62. Finer N, James WP, Kopelman PG, et al. One-year treatment of obesity: a randomized, double-blind, placebo-controlled, multicentre study of orlistat, a gastrointestinal lipase inhibitor. Int 7 Obes Relat Metab Disord 2000;24:306-13.

63. Hanefeld M, Sachse G. The effects of orlistat on body weight and glycaemic control in overweight patients with type 2 diabetes: a randomized, placebocontrolled trial. Diabetes Obes Metab 2002;4:415-23.

64. Hauptman J, Lucas C, Boldrin MN, et al. Orlistat in the long-term treatment of obesity in primary care settings. Arch Fam Med 2000;9:160-7.

65. Hollander PA, Elbein SC, Hirsch IB, et al. Role of orlistat in the treatment of obese patients with type 2 diabetes. A 1-year randomized double-blind study. Diabetes Care 1998;21:1288-94.
66. Krempf M, Louvet JP, Allanic H, et al. Weight reduction and long-term maintenance after 18 months treatment with orlistat for obesity. Int 7 Obes Relat Metab Disord 2003;27:591-7.

67. Lindgärde F. The effect of orlistat on body weight and coronary heart disease risk profile in obese patients: the Swedish Multimorbidity Study. 7 Intern Med 2000;248:245-54

68. Miles JM, Leiter L, Hollander P, et al. Effect of orlistat in overweight and obese patients with type 2 diabetes treated with metformin. Diabetes Care 2002;25:1123-8.

69. Rössner S, Sjöström L, Noack R, et al. Weight loss, weight maintenance, and improved cardiovascular risk factors after 2 years treatment with orlistat for obesity. European Orlistat Obesity Study Group. Obes Res 2000;8:49-61.

70. Sjöström L, Rissanen A, Andersen T, et al. Randomised placebo-controlled trial of orlistat for weight loss and prevention of weight regain in obese patients. European Multicentre Orlistat Study Group. Lancet 1998;352:167-72.

71. Swinburn BA, Carey D, Hills AP, et al. Effect of orlistat on cardiovascular disease risk in obese adults. Diabetes Obes Metab 2005;7:254-62.

72. Torgerson JS, Hauptman J, Boldrin MN, et al. XENical in the prevention of diabetes in obese subjects (XENDOS) study: a randomized study of orlistat as an adjunct to lifestyle changes for the prevention of type 2 diabetes in obese patients. Diabetes Care 2004;27:155-61.

73. Bakris G, Calhoun D, Egan B, et al. Orlistat improves blood pressure control in obese subjects with treated but inadequately controlled hypertension. 7 Hypertens 2002;20:2257-67.

74. Kelley DE, Bray GA, Pi-Sunyer FX, et al. Clinical efficacy of orlistat therapy in overweight and obese patients with insulin-treated type 2 diabetes: a 1-year randomized controlled trial. Diabetes Care 2002;25:1033-41.

75. Van Gaal LF, Broom JI, Enzi G, et al. Efficacy and tolerability of orlistat in the treatment of obesity: a 6-month dose-ranging study. Orlistat Dose-Ranging Study Group. Eur 7 Clin Pharmacol 1998;54:125-32.

76. Muls E, Kolanowski J, Scheen A, et al; ObelHyx Study Group. The effects of orlistat on weight and on serum lipids in obese patients with hypercholesterolemia: a randomized, double-blind, placebo-controlled, multicentre study. Int 7 Obes Relat Metab Disord 2001;25:1713-21.

77. Broom I, Hughes E, Dodson P, et al.; ORILSTAT UK Study Group. The role of orlistat in the treatment of obese patients with mild to moderate hypercholesterolaemia: consequences for coronary risk. Brit 7 Cardio. 2002;9:460-8.

78. Seifarth C, Schehler B, Schneider HJ. Effectiveness of metformin on weight loss in non-diabetic individuals with obesity. Exp Clin Endocrinol Diabetes 2013;121:27-31.

79. Smith SR, Stenlof KS, Greenway FL, et al. Orlistat $60 \mathrm{mg}$ reduces visceral adipose tissue: a 24-week randomized, placebo-controlled, multicenter trial. Obesity (Silver Spring) 2011;19:1796-803.

80. Thomas EL, Makwana A, Newbould R, et al. Pragmatic study of orlistat $60 \mathrm{mg}$ on abdominal obesity. Eur 7 Clin Nutr 2011;65:1256-62.

81. He H, Zhao Z, Chen J, et al. Metformin-based treatment for obesity-related hypertension: a randomized, double-blind, placebo-controlled trial. 7 Hypertens 2012;30:1430-9.

82. Fontbonne A, Charles MA, Juhan-Vague I, et al. The effect of metformin on the metabolic abnormalities associated with upper-body fat distribution. BIGPRO Study Group. Diabetes Care 1996;19:920-6.

83. Lim SS, Norman RJ, Clifton PM, et al. The effect of comprehensive lifestyle intervention or metformin on obesity in young women. Nutr Metab Cardiovasc Dis 2011;21:261-8.

84. The Diabetes Prevention Program. Design and methods for a clinical trial in the prevention of type 2 diabetes [published erratum in Diabetes Care 1999; 22:1389]. Diabetes Care 1999;22:623-34.

85. Lau DC, Teoh H. Benefits of modest weight loss on the management of type 2 diabetes mellitus. Can 7 Diabetes 2013;37:128-34.

86. Health Topics Diabetes: Data and Statistics. Geneva (Switzerland): World Health Organization; 2013.Available: www.euro.who.int/en/health-topics /noncommunicable-diseases/diabetes/data-and-statistics (accessed 2014 Sept. 17).

87. Siebenhofer A, Jeitler K, Berghold A, et al. Long-term effects of weightreducing diets in hypertensive patients. Cochrane Database Syst Rev 2011;(9): CD008274.

88. Ross SA, Dzida G, Vora J, et al. Impact of weight gain on outcomes in type 2 diabetes. Curr Med Res Opin 2011;27:1431-8.

89. Gillett $M$, Royle P, Snaith A, et al. Non-pharmacological interventions to reduce the risk of diabetes in people with impaired glucose regulation: a systematic review and economic evaluation. Health Technol Assess 2012;16:1-236, iii-iv.

Affiliations: McMaster Evidence Review and Synthesis Centre (Peirson, Ciliska, Fitzpatrick-Lewis, Ali, Raina), McMaster University Hamilton, Ont.; Department of Medicine (Douketis), McMaster University, Hamilton, Ont.; St. Joseph's HealthCare (Douketis), Hamilton, Ont.

Contributors: Leslea Peirson, Donna Ciliska, James Douketis, Donna Fitzpatrick-Lewis and Parminder Raina were involved in conceptualizing the study, data interpretation and writing the manuscript. Leslea Peirson, Donna Ciliska and Donna Fitzpatrick-Lewis were involved in developing the methods, collecting the data and coordinating the project. Muhammad 
Usman Ali conducted the data analyses and contributed to writing the manuscript. All of the authors revised the manuscript, approved the final version submitted for publication and agreed to act as guarantors of the work.

Competing interests: Donna Ciliska and Parminder Raina have received grants from the Canadian Institutes of Health Research. James Douketis is a current member of the advisory boards for Bayer, Bristol-Myers Squibb, Sanofi and Pfizer. He was a member of the advisory boards for AstraZeneca, Boehringer Ingelheim, Biotie Therapies, Portola Pharmaceuticals and The Medicines Company. He also received speaker fees from AGEN Biomedical, Ortho-Janssen Pharmaceuticals and Boehringer Ingelheim, as well as a grant from Boehringer Ingelheim. None others declared.

Funding: Funding was provided by the Canadian Institutes of Health Research (CIHR; www.cihr-irsc.gc.ca). The CIHR played no role in the study design, data analysis, interpretation or decision to submit the paper for publication. Parminder Raina holds a Tier 1 Canada Research Chair in Geroscience and the Raymond and Margaret Labarge Chair in Research and Knowledge Application for Optimal Aging.
Disclaimer: The views expressed herein are the opinions of the authors and do not necessarily represent the views of the CIHR.

Acknowledgements: Rachel Warren, Meghan Kenny, Eva Tsakonas and Mary Gauld contributed to the relevance and quality assessment, and dataextraction phases. We are grateful to Maureen Rice for the search, Eva Tsakonas for contextual questions (results not reported here) and to Sharon Peck-Reid for database management and formatting of the report. Sarah Connor Gorber and Amanda Shane (Scientific Officers, Public Health Agency of Canada) contributed to the original protocol development and review of drafts of the technical report. Similarly, Paula Brauer, Maria Bacchus, Neil Bell, Elizabeth Shaw and Harminder Singh (members of the Adult Obesity Working Group of the Canadian Task Force on Preventive Health Care) provided comments on the protocol and initial analyses. The Task Force Chair, Cello Tonelli, provided valuable feedback on the manuscript.

Supplemental information: For reviewer comments and the original submission of this manuscript, please see www.cmajopen.ca/content/2/4 /E306/suppl/DC1 